\title{
PENGARUH MEDIA DALAM LAYANAN BIMBINGAN KELOMPOK TERHADAP PENGATURAN DIRI SISWA KELAS XI DI SMAN 56 JAKARTA
}

\author{
Rima Hazrati ${ }^{1}$ \\ Wirda Hanim ${ }^{2}$ \\ Dharma Setiawaty R. ${ }^{3}$
}

\begin{abstract}
Abstrak
Penelitian ini bertujuan untuk mengetahui perbedaan pengaturan diri antara siswa dalam bimbingan kelompok yang menggunakan media dengan siswa yang hanya mengikuti bimbingan kelompok tanpa menggunakan media pada siswa kelas XI IPS SMAN 56 Jakarta. Penelitian ini adalah eksperimen semu (quasi eksperiment). dengan rancangan "post test only control group design". Populasi dalam penelitian ini adalah siswa kelas XI IPS SMAN 56 Jakarta. Sampel penelitian sebanyak 20 orang siswa diambil menggunakan teknik sampling purposive sampling. Sampel terbagi dua kelompok yaitu kelompok eksperimen dan kelompok kontrol. Pengukuran pada penelitian ini menggunakan instrument pengaturan diri. Berdasarkan hasil uji, instrumen ini memiliki 12 pernyataan yang valid dengan reliabilitas sebesar 0,718, hal tersebut menyimpulkan bahwa instrument ini layak dijadikan alat ukur dalam penelitian. Teknik analisisi data untuk menguji hipotesis menggunakan Wilcoxon Match Pairs didapatkan hasil Asymp. Sig. (2 tailed) sebesar 0.012 yang berarti lebih kecil dari nilai signifikan $\alpha=0,05$, sehingga $\mathrm{H} 0$ ditolak dan $\mathrm{H} 1$ diterima, yaitu terjadi perbedaan yang signifikan setelah diberikan layanan bimbingan kelompok dengan media. Kesimpulannya berdasarkan hasil penelitian ini, penggunaan media dalam layanan bimbingan kelompok dapat diterapkan terhadap pengaturan diri siswa kelas XI IPS SMAN 56 Jakarta.
\end{abstract}

Kata kunci: media, bimbingan kelompok, pengaturan diri

\section{PENDAHULUAN}

Maraknya beberapa kasus yang ada dimasyarakat seperti pencurian, korupsi, pembunuhan, pembegalan, tawuran dan narkoba salah satunya disebabkan oleh individu yang tidak dapat mengontrol/ mengatur emosinya dengan baik. Ketidak mampuan mengontrol hawa nafsu dan emosi menyebabkan individu menjadi kehilangan kendali sehingga rela melakukan apapun untuk memenuhi keinginannya. Tidak hanya dikalangan orang dewasa, para pelajar pun banyak yang sulit mengendalikan emosi sehingga melakukan tindakan negatif seperti yang telah disebutkan sebelumnya.

Pada kenyataannya di lapangan, masih sering terjadi peristiwa yang menunjukkan rendahnya pengelolaan emosi pada siswa, salah satu diantaranya adalah peristiwa tawuran Kebanyakan para pelajar yang terlibat kasus berada dalam usia remaja yaitu antara 12-21 tahun. Adanya beberapa siswa yang belum memenuhi tugas perkembangannya dengan baik. Oleh karenanya dibutuhkan pendidikan yang mampu membina para siswa untuk dapat mengelola emosinya dan memenuhi tugas

\footnotetext{
${ }^{1}$ Mahasiswa Program Studi Bimbingan dan Konseling FIP UNJ, rimarizra@gmail.com

${ }^{2}$ Dosen Program Studi Bimbingan dan Konseling FIP UNJ

${ }^{3}$ Dosen Program Studi Bimbingan dan Konseling FIP UNJ
} 
perkembangannya dengan baik.

Banyak pergaulan para siswa yang kurang sehat seperti merokok, mencuri, membolos, tawuran, membully dll disebabkan kurangnya pembinaan moral terutama ketrampilan mengelola emosi di setiap sekolah untuk membentuk sikap dan perilaku positif. Selain itu, adanya beberapa siswa yang belum memenuhi tugas perkembangannya dengan baik. Oleh karenanya dibutuhkan pendidikan yang mampu membina para siswa untuk dapat mengelola emosinya dan memenuhi tugas perkembangannya dengan baik. Pendidikan adalah suatu usaha atau kegiatan yang dijalankan dengan sengaja, teratur dan berencana dengan maksud mengembangkan perilaku yang diinginkan.

Berdasarkan penjelasan di atas, maka pengaturan diri dalam emosi merupakan hal yang penting. Pengaturan diri dalam emosi tersebut merupakan komponen dalam kecerdasan emosional. Hal tersebut berkaitan karena dengan pengaturan diri yang baik maka dapat menunjang individu untuk bisa memiliki kecerdasan emosi yang baik pula.

Setelah peneliti melakukan studi pendahuluan dengan menyebarkan kuisioner pengaturan diri kepada peserta didik kelas XI di SMAN 56 Jakarta Barat yang berjumlah 36 orang, didapatkan hasil sebagai berikut : siswa yang memiliki pengaturan diri tinggi mencapai $36,1 \%$ (13 orang), sedang $1,66 \%$ (6 orang), dan rendah 47,2\% (17 orang).

Hasil yang didapatkan dari pemaparan kuisioner yang telah disebar ialah beberapa siswa tidak mampu bersikap tenang dalam menghadapi masalah, tidak mudah untuk menghibur diri sendiri ketika murung, tidak tau apa yang harus dilakukan saat menghadapi kesulitan, terus memikirkan hal yang membuat kecewa, merasa tidak memiliki kelebihan, enggan mengucapkan terima kasih kepada orang lain, enggan membantu teman dalam kesusahan, malas mengikuti ujian remedial, merasa banyak yang tidak mau berteman dengan nya, marah dan kesal jika keinginannya tidak terpenuhi. Dari hasil pengolahan menggunakan skala likert yang peneliti lakukan, dapat disimpulkan bahwa beberapa siswa memiliki kecerdasan emosional yang rendah.

Upaya meningkatkan pengaturan emosi diri siswa dapat memanfaatkan layanan bimbingan dan konseling. Salah satu layanan yang dapat diberikan oleh konselor yaitu bimbingan kelompok. Gazda dalam Prayitno (2004) menjelaskan istilah bimbingan kelompok di sekoah sebagai kegiatan informasi kepada sekelompok peserta didik untuk membantu mereka menyusun rencana dan keputusan yang tepat. Bimbingan kelompok diselenggarakan untuk memberikan informasi yang bersifat personal, vokasional, dan sosial.

Pelaksanaan bimbingan kelompok memerlukan pemilhan media untuk memudahkan peserta didik dalam menerima informasi yang disampaikan konselor. Media bimbingan dan konseling merupakan salah satu media yang dapat digunakan dalam layanan bimbingan kelompok. Banyak macam media yang dapat digunakan seperti, video animasi, modul, komik, popup dll Media bimbingan dan konseling yang digunakan disesuaikan dengan karakteristik peserta didik kelas XI SMA.

Berdasarkan latar belakang permasalahan yang telah diuraikan, maka peneliti merasa perlu mengkaji secara ilmiah melalui penelitian tentang pengaruh media dalam layanan bimbingan kelompok dapat berpengaruh positif terhadap pengaturan diri siswa kelas XI IPS di SMAN 56 Jakarta. 
KAJIAN TEORI

\section{KECERDASAN EMOSI}

Menurut Goleman (2003)

kecerdasan emosi dapat didefinisikan sebagai kemampuan mengenali perasaan diri sendiri dan perasaan orang lain kemampuan memotivasi diri sendiri, dan kemampuan mengelola emosi dengan baik pada diri sendiri dan dalam membina hubungan dengan orang lain. 5 (lima) wilayah kecerdasan emosional yang dapat menjadi pedoman bagi individu untuk mencapai kesuksesan dalam kehidupan sehari-hari, yaitu kesadaran diri, pengaturan diri, motivasi, empati, ketrampilan sosial.

Dalam penelitian ini, peneliti hanya menggunakan satu aspek yaitu aspek Pengaturan Diri. Hal tersebut disesuikan dengan fenomen siswa yang diteliti. Menurut Averill dalam Edward (2006), pengaturan diri merupakan kemampuan seseorang dalam mengelola emosi untuk membuat keputusan dalam mengekspresikan perasaan atau tindakan. Aspek dari pengaturan diri itu sendiri ialah Pengaturan diri : menangani emosi kita sedemikian sehingga berdampak positif kepada pelaksanaan tugas; peka terhadap kata hati dan sanggup menunda kenikmatan sebelum tercapainya suatu sasaran; mampu pulih kembali dari tekanan emosi.

\section{MEDIA BIMBINGAN DAN KONSELING}

Menurut Mochamad Nursalim (2015) Media Bimbingan dan Konseling adalah segala sesuatu yang dapat digunakan untuk menyalurkan pesan bimbingan dan konseling yang dapat merangsang pikiran, perasaan, perhatian, dan kemauan siswa/ konseli untuk memahami diri, mengarahkan diri, mengambil keputusan serta memecahkan masalah yang dihadapi.

Klasifikasi media yang akan digunakan peneliti ialah Media Bahan Cetak dan Media Film. Media bahan cetak adalah media visual yang pembuatannya melalui proses pencetakan/printing atau effek. Sementara media Film adalah yaitu serangkaian gambar diam yang meluncur secara cepat dan diproyeksikan sehingga menimbulkan kesan hidup dan bergerak.

\section{BIMBINGAN KELOMPOK}

Menurut Prayitno (1995) layanan bimbingan kelompok adalah suatu layanan bimbingan yang di berikan kepada siswa secara bersama-sama atau kelompok agar kelompok itu menjadi besar, kuat, dan mandiri.

Menurut Hallen (2005) tujuan dari layanan bimbingan kelompok yaitu untuk mengembangkan langkah-langkah bersama untuk menangani permasalahan yang dibahas di dalam kelompok dengan demikian dapat menumbuhkan hubungan yang baik antar anggota kelompok, kemampuan berkomunikasi antar individu, pemahaman berbagai situasi dan kondisi lingkungan, dapat mengembangkan sikap dan tindakan nyata untuk mencapai hal-hal yang di inginkan sebagaimana terungkap di dalam kelompok. Bimbingan kelompok memiliki 4 tahapan yaitu tahap pembukaan, tahap peralihan, tahap inti, tahap pengakhiran.

\section{METODOLOGI PENELITIAN}

Penelitian ini dilakukan pada 10 orang siswa kelas XI IPS 3 SMAN 56 Jakarta yang memiliki skor total rendah. Penelitian ini dilakukan pada bulan Oktober - Desember 2015. Penelitian ini dilakukan sebanyak 5 kali pertemuan kegiatan bimbingan kelompok dan satu kali pertemuan pemberian posttest. Kegiatan ini dilakukan di Ruang BK SMAN 56 Jakarta.

Metode yang digunakan dalam penelitian ini adalah quasi eksperimen dengan desain penelitian menggunakan "PosttestOnly Control Design". Teknik sampling yang digunakan adalah sampling purposive karena hanya siswa yang memiliki skor total rendah yang menjadi subjek penelitian.

Penelitian ini menggunakan kuesioner :pengaturan diri" untuk melihat perbedaan antara kelompok kontrol dengan kelompok eksperimen dengan menggunakan skala likert dalam menganilisa skor. Setelah dilakukan uji coba instrument pada 65 
responden didapat 12 item yang valid dan tidak ada yang tidak valid/di drop. Sedangkan berdasarkan rumus alpha cronbach didapat nilai reliabilitas sebesar 0,718 yang berarti cukup.

Analisa data hasil digunakan rumus wilcoxon match pairs test karena dalam analisa membandingkan dua data (kelompok kontrol dan kelompok eksperimen). Berdasarkan analisa data dapat dilihat ada atau tidak pengaruh penggunaan media terhadap pengaturan diri siswa.

\section{HASIL DAN PEMBAHASAN}

Berdasarkan hasil posttest yang dilakukan pada kelompok eksperimen dan kelompok kontrol dengan masing-masing terdiri dari 10 orang siswa kelas XI IPS 3 SMA Negeri 56 Jakarta didapatkan hasil sebagai berikut:

Tabel 1

Hasil Posttest Kelompok Eksperimen dan Kelompok Kontrol

\begin{tabular}{cccc}
\hline Kelompok & $\begin{array}{c}\text { Skor } \\
\text { Ideal }\end{array}$ & $\begin{array}{c}\text { Skor } \\
\text { Rata-Rata } \\
\text { Posttest }\end{array}$ & $\%$ \\
\hline $\begin{array}{c}\text { Kelompok } \\
\text { Eksperi- } \\
\text { men }\end{array}$ & 48 & 40,6 & 84,56 \\
$\begin{array}{c}\text { Kelompok } \\
\text { Kontrol }\end{array}$ & 48 & 36,8 & 76,66 \\
\hline
\end{tabular}

Berdasarkan hasil posttest pada dua kelompok yaitu kelompok eksperimen dan kontrol memiliki perbedaan yang cukup signifikan. Kelompok eksperimen setelah diberikan perlakuan memiliki skor 84,56 $\%$ sedangkan kelompok kontrol yang tidak diberikan perlakuan memiliki skor 76,66. Hal tersebut dapat diartikan bahwa adanya pengaruh yang signifikan penggunaan media bimbingan konseling dalam layanan bimbingan kelompok untuk meningkatkan pengaturan diri siswa. Berikut hasil dalam bentuk grafik :

\section{Grafik 1}

Hasil Posttest Kelompok Eksperimen dan Kelompok Kontrol

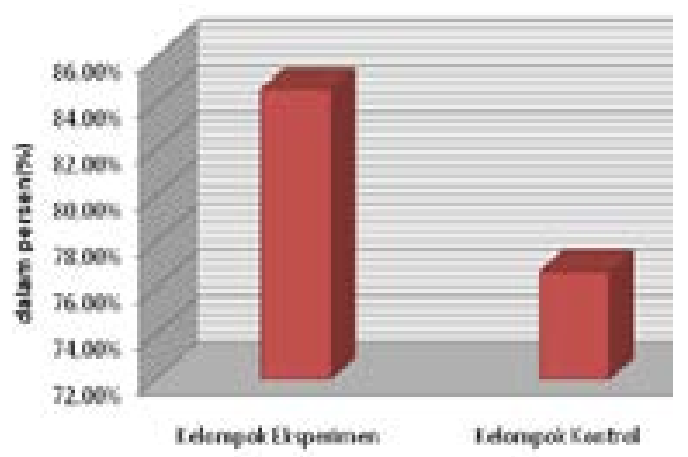

Berdasarkan hasil post test terhadap 10 orang siswa kelompok eksperimen dan 10 orang siswa kelompok kontrol menunjukkan bahwa skor tertinggi adalah 43 dan skor terendah adalah 33 .

Tabel 2

Deskripsi Hasil Posttest per Siswa

\begin{tabular}{ccccc}
\hline $\begin{array}{c}\text { Kelom- } \\
\text { pok }\end{array}$ & $\begin{array}{c}\text { Skor } \\
\text { Ideal }\end{array}$ & Nama & \multicolumn{2}{c}{ Skor } \\
Eksperi- & 48 & JP & 42 & 87,50 \\
men & & GP & 41 & 84,40 \\
& & MM & 39 & 81,25 \\
& & SA & 40 & 83,30 \\
& & LR & 40 & 83,30 \\
& & AN & 40 & 83,30 \\
& & WA & 43 & 89,50 \\
& & MI & 40 & 83,30 \\
& & SC & 41 & 84,40 \\
& & SNF & 40 & 83,30 \\
\hline
\end{tabular}

\begin{tabular}{ccccc}
\hline $\begin{array}{c}\text { Kelom- } \\
\text { pok }\end{array}$ & $\begin{array}{c}\text { Skor } \\
\text { Ideal }\end{array}$ & Nama & \multicolumn{2}{c}{ Skor } \\
\hline Kontrol & 48 & AH & 37 & 77,00 \\
& & DM & 34 & 70,80 \\
& & DWE & 37 & 77,00 \\
& & FL & 33 & 68,75 \\
& & IS & 36 & 75,00 \\
& & KK & 35 & 72,90 \\
& & MY & 35 & 72,90 \\
& & MRP & 41 & 85,40 \\
& & NH & 42 & 87,50 \\
& & SS & 38 & 79,10 \\
\hline
\end{tabular}


Uji hipotesis yang dilakukan dengan menggunalan rumus wilcoxon untuk melihat signifikansi digunakan SPSS 17 , didapat bahwa nilai kelompok eksperimen $>$ kelompok kontrol. nilai Asymp. Sig $=0.012$ yang berarti nilai probabilitas lebih kecil dari nilai signifikansi $\alpha=0.05$. Dengan demikian dapat disimpulkan bahwa Ho ditolak dan $\mathrm{H} 1$ diterima, yaitu terjadi peningkatan pengaturan diri setelah diberikan treatment. Maka dapat disimpulkan bahwa, terdapat pengaruh media bimbingan konseling terhadap pengaturan diri SMA Negeri 56 Jakarta.

\section{KESIMPULAN DAN SARAN}

Layanan bimbingan kelompok dengan media memiliki pengaruh yang signifikan terhadap peningkatan pengaturan diri siswa. Berdasarkan Hasil pengujian hipotesis dengan menggunakan Wilcoxon Match Pairs didapatkan hasil Asymp. Sig. (2 tailed) sebesar 0.012. Hipotesis penelitian diuji pada taraf $\alpha=0,05$ atau dengan tingkat kesalahan 5\%, maka nilai Sig. (2 tailed) sebesar $0.012<$ nilai signifikan $\alpha=0,05$, maka dapat disimpulkan bahwa H0 ditolak dan H1 diterima. Ini mengartikan bahwa terjadi peningkatan pada pengaturan diri siswa kelas XI IPS di SMAN 56 Jakarta setelah diterapkan media dalam bimbingan kelompok.

Peningkatan pengaturan diri siswa dalam layanan bimbingan kelompok dapat dicapai dengan penggunaan media, dimana siswa dapat mempelajari contoh-contoh yang terdapat pada pengaturan diri, serta memperoleh penguatan dan motivasi. Dengan demikian, siswa memiliki kemampuan untuk mengelola perasaan, mampu mengelola ego dengan baik. oleh karena itu, layanan bimbingan kelompok dengan media bimbingan konseling merupakan salah satu alternatif yang dapat dipilih untuk diterapkan dan terus dikembangkan. Selain itu media dapat digunakan secara berulang-ulang dan membuat suasana belajar mengajar menjadi tidak membosankan.

Saran saran yang dapat dijadikan pertimbangan berdasarkan hasil penelitian yang telah dilakukan bagi guru BK ialah Media digunakan sebagai bahan masukan bagi praktisi pendidikan baik orang tua, guru, karyawan dan pihak sekolah yang lain, untuk bisa memanfaatkan media yang ada, dan membuat media sendiri yang efektif, efisien, ekonomis, dan tahan lama karena mengingat betapa pentingnya media dalam pendidikan. Bagi Program Studi Bimbingan dan Konseling Pemanfaatan dan pengembangan media dapat disisipkan dalam mata kuliah Media BK agar mahasiswa dapat lebih kreatif. Selain itu pembuatan instrumen dapat dikembangkan lagi melalui mata kuliah Asesmen. Dan bagi peneliti lain Sebaiknya mempersiapkan diri sendiri dengan strategi dan media yang dibutuhkan dan ragam media sebanyak mungkin, agar siswa dapat lebih banyak belajar dari media - media yang ditampilkan tersebut.

\section{DAFTAR PUSTAKA}

Edward, P. Sarafino. (2006). Health Psychology: Biopsychosocial Interactions (5th ed.). (New Jersey: John Willey \& Sons.

Goleman, D. (2003). Kecerdasan Emosi untuk Mencapai Puncak Prestasi,Terjemahan: Alex Tri Kantjono. Jakarta: Gramedia Pustaka Utama

Hallen, A. (2005). Bimbingan dan Konseling. Jakarta: Quantum Teaching.

Nursalim, M. (2015). Pengembangan Media Bimbingan dan Konseling. Jakarta: Indeks.

Prayitno.(1995). Layanan Bimbingan dan Konseling Kelompok: Dasar dan Profil. Jakarta: Ghalia Indonesia.

Prayitno. (2004). Dasar-Dasar Bimbingan dan Konseling. Jakarta: Rineka Cipta. 
